\title{
The Role of War Game in Educating and Training the Commanders
}

\author{
Mislat Safar Almuqati, Nurazmallail Marni* \\ Academy of Islamic Civilization, Faculty of Social Science and Humanities, Universiti Teknologi Malaysia, 81310 UTM \\ Johor Bahru, Johor \\ *Corresponding author: nurazmal@utm.my
}

\begin{abstract}
Article history
Received: 2017-08-08 Received in revised form: 2019-07-03 Accepted: 2019-07-04 Published online: 2019-10-31
\end{abstract}

\begin{abstract}
The war game is considered to be the most effective means of military training due to the fact that it simulates the reality since it provides a semi-real picture of the weapons and equipment used in the training. Consequently, it provides the trainee with the appropriate environment to freely deal with such weapons as well as military equipment which in turn help the trainee become acquainted with all aspects of use and significantly instill confidence in him when such equipment are actually needed in war. More importantly, war game provides environment similar to what is going on in the actual battlefields allowing the commanders to exercise the training as if they were in a real war. Based on this perspective, the war game has emerged as an advanced training means which provides an analogy of the battle atmosphere to a great extent and gives commanders the opportunity to make decisions. It also helps in providing the commanders with a future view which enables them to plan their future and to deal with any challenges they might encounter. In fact, the role of war play is not only limited to training, but also extends to the aspects of military education, preparation, and development. The notion of war game is not only a means for the commander to have knowledge about the war before it occurs so as to be able to realize whether the decisions taken are right or wrong, but also it has become an effective means on which the armies depend when they train and polish the commanders' capabilities as well as skills. In fact, the concept of war play is not exclusive to the military field but also it is employed by all agencies and departments that require a future vision in training or planning. This paper sheds some light on the notion of war game and its role in training and educating the commanders and staff.
\end{abstract}

Keywords: War game - Military Commanders

\subsection{INTRODUCTION}

War game is considered to be the most recent means to educate commanders when it is used wisely. It provides a strong impact and plays an effective role in training and preparing the armed forces as it offers many advantages which are extremely helpful in various phases of preparation as well as development. This will in turn assist in developing the armed forces which ensures its military superiority (Perla, 1990).

The significance of war game lies in the fact that it achieves the requirements which were previously impossible to attain. War game depicts the battle events as well as the nature of its territory and also represents the enemy forces with all its potential. It also helps predict the future events and what will accrue to the battles. 
In addition, war game provides the commanders with enough room and wide horizon so that they can test their abilities, polish their skills and experience their decisions (Peterson, 2012). Therefore, attention must be paid to war game and every endeavor must be paid to use it in all fields of the armed forces and also great efforts must be made to get benefits from its potential. This paper sheds some light on the notion of war game and its role in training and educating the commanders and staff.

\subsection{THE NOTION OF WAR GAME}

The notion of war game might be unclear to some extent due to the secrecy that surrounds such a concept in that it is closely associated with military decision-making since its inception (Perla, 1990). To resolve this ambiguity, the linguistic meaning as well as the military concept for both words "game" and "war" will be provided and then other definitions of these words in literature and the researcher's definition will be provided.

\subsection{Definitions of the Word "Game"}

The word "game" is plural in Arabic and has its singular form "lucbah". Ibn Manzur (1968, p. 741) illustrated the meaning of this word in his famous dictionary the Tongue of Arab "Lisān AlArab" claiming that "lucbah" is a kind of play and the play is what it is played with such as chess and the like and all what can be played with is play". In terms of the definition of play in the military environment, Abed (1994, p. 47) in his article on the war play in the National Guard Magazine argued that "it is an exercise in which people represent themselves or play other roles in a real or similar environment".

\subsection{Definition of the Word "War"}

In linguistics, Ibn Manzur (1968, p. 302) in his famous dictionary "Lisān Al-Arab" claimed that war is the opposite of peace and it is originally an adjective in a phrase like "muqātilatu harb" literally as a war fighter". Overall, the word "war" has many definitions including the definition of Al-Omari (2002) who pointed out, in his article on war management by computers in the Military Magazine of King Abdul Aziz, that the war is "the use of all the political, military, intellectual, economic and moral potential of the nation and any other potential as either actual use or as some sort of threatening in order to impose a solution that achieves the national interest in any kind of conflict or at any stage of its infancy". Moreover, Al-Shahri (1999, p. 27) defined the word "war", in his article entitled "The Evolution of War Throughout History in the Magazine of the National Saudi Guard, as "a legal basis which allows two or more groups which are in conflict to resolve the dispute through the armed forces".

From what has been discussed earlier, it can be concluded that the war is a fight which takes place between two armed groups using all means of force so as to achieve the goals behind the war. This war usually results in the depletion of the resources of the country along with the tragic loss of lives and properties.

\subsection{Definition of War Game}

There are many synonymous words used for "war game"; any one of which provides the same meaning. These synonyms include the war game, war tournament, war plays, and war games. AlPage $\mid 2$ 
Zaini (1997, p. 71) maintained, in his article entitled war tournaments by computer in the Gulf Defense Magazine, that war game "is a huge programmed model which performs the events of war and is used as a substitute for it". In the guide of war tournaments issued by the Faculty of Command and Staff, Egyptian Command and Staff College in (2000, p. 3), the concept of war tournament was defined as "a perception of potential conflict- military conflict- between the parties having conflicting goals and each party tries to know the strategy of the other party in order to take all the necessary actions and precautions to conceal its strategy seeking any other information about the other party".

Based on the previously-mentioned definitions with their different denotations, the researcher has come up with this definition of war game; it is a practical exercise analogous to a real or presumed battle in which the players (trainees) are allowed to carry out the roles of commanders and staff to manage the battle and make decisions in order to obtain certain results related to training, investigation and analysis.

\subsection{THE ROLE OF WAR PLAY IN BUILDING THE PERSONALITY OF COMMANDERS AND POLISHING THEIR SKILLS}

Nobody can deny the significance of the roles assigned to the commanders with different levels and the magnitude of the responsibility they shoulder (Johnson, 2014). In fact, failure or success of a military unit is usually attributed to their leadership. Therefore, attention must be paid to rehabilitate and train the commanders so as to qualify them to become capable of exploiting the available potential, performing the duties of management, planning and preparation for those whom they are responsible for, seeking to promote their military units to the highest degree of preparation.

The leadership is more significant in the war than in peace because the commander's error has a negative impact not only on the individuals but on the entire military unit. Tse (1995, p. 28) argued, in his book "The Art of War" which was translated by Meftah, that there are five main defects which may affect the commander's performance in the battle, namely, first, if the commander is reckless, he can be killed, and if he is a coward, there is a possibility to be captured. If the commander has a severe mood, he can become angry and might commit mistakes. The fourth defect that may affect the commander's performance is the case when he is sensitive toward dignity which may result in provoking him by offense. The fifth defect can be realized when he is compassionate in nature which makes him disturbed and annoyed. These five defects of the commander can pull him down and deterred him to continue the battle. Such defects can inevitably result in the destruction of the army and the death of the commander and they should be studied carefully and in-depth. War game is the best way to investigate these mistakes and defects and train the commanders to overcome such challenges through doing more exercises in situations similar to what happen in the battle in front of the commanders and having knowledge on how to deal with them, and thus taking the necessary training procedures. The war game has an effective role in training and rehabilitating the commanders and polishing their skills since it provides them with the following skills and expertise:

\subsection{Ability to Make Decisions}

One of the clearest definitions of the decision is the one provided by Al-Otaibi (1998, p. 145) in his article "science and art of comparing and selecting weapons" in the magazine of the National Saudi Guard, in which he claimed that "the decision is the process of selecting one alternative from several 
alternatives, and this choice is made after extensive analytical investigation of all aspects of the problem". This means that the decision is the best available alternative whose selection is made by the commander and thus such a commander must have the ability to make a good choice. Asiri (2001, p. 108) claimed that "decision-making is not an easy matter in that it is built mainly on the advanced planning which includes a good estimate of the situation on the light of the available information, the circumstances surrounding it and the available potential for the decision-maker. Moreover, Asiri maintained that the more accessible, complete and accurate the information is, the more appropriately the decision can be made". Here, the role of war game is to give the commander the opportunity to test themselves in the decision-making without any hesitation. The decisions taken here do not have any negative influence as those taken in the battlefield.

In war game, the commanders have an opportunity to make various decisions even if they were wrong because such decisions will then be studied and analyzed to determine their weaknesses and consequently they must be avoided in the real battle and also the gaps in such decisions must be bridged through more exercises, all of which must be conducted to enable the commander to take the right decisions. Therefore, the door is open for the commanders to use the war game where they can experience decision-making, do much more practice and improve their abilities. Consequently, the use of war game in this field will significantly lead to appropriately make good decisions which can put an end to different issues.

\subsection{Future Vision And How To Deal With Emergency Events}

Courtois (1998, p. 99) claimed, in his book "Profiles in the Art of Leadership", that "the success and failure of the leader (commander) greatly depend on his realistic expectations and deep perception of the future. The successful commander does not plan for a day only, but also he should have plans for the future. He should set some objectives for the future, expect future consequences for the decisions he makes and expect all the challenges as well as obstacles he might encounter in the future. Doing this should not be a reason to reduce his enthusiasm but he should provide some solutions for the expected challenges (Schuurman, 2017, p. 443).

Predicting the future events in the battlefield provides many benefits for the commanders as it helps him avoid improvised reactions when the situations get worse and when the unexpected events take place. Thus, the commander (leader) who does not plan his future well, he might encounter sudden events which he does not expect and as a result he might be incapable of handling such events and might commit some mistakes and fail eventually. So whenever the vision is more pronounced for the future, the decisions taken will be more appropriate.

The war game is considered to be the best means to help predict what will happen in the future since it provides the commanders with a wide field for investigation and analysis through predicting what will happen in the future battlefield. In particular, it helps predict the activities and the moves of the enemy as well as the bulk and type of military forces, all of which lead to more understanding about the enemy and the enemy's intensions. It also helps predict the results of our troops' activities during various stages of the battle, predicting the ultimate outcome of the battle (Peterson, 2012).

The three previously-mentioned benefits are only the outcome of exercising the war game due to the fact that it provides the possibility of having knowledge about the reactions and the reactions from

Page $\mid 4$ 
the other party. These are only expectations because of the fact that none certainly knows what will happen in the battles except Allah. The use of war play is not limited to what happens on the battlefield since it can be also used by the commanders to develop and train their military units, providing a future vision helpful in conducting different exercises.

\subsection{Gaining a High Level of Experience}

The military history is full of events and lessons which might benefit the commanders if they are analyzed and understood. Such events can benefit the commanders a lot in terms of the battles, the nature of the battle, and how the formers commanders dealt with the challenges they had encountered in the battles. However, the military history does not provide the commanders with sufficient experience similar to the experience gained from the real battles (Peterson, 2012). It is naive to fight in a battle without enough experience and sufficient exercises which ensure the success. Hence, the war game is the best way to gain experience because it provides the commanders with a clear picture of the battle and also is an opportunity for the commanders to exercise the wars for training purposes. As a result, the commanders gain a lot of experiences and have knowledge which enables them to deal with similar events in the real war.

So the war game polishes the skills of the commanders, training them on how to deal with fighting situations as if they were real. In other words, the war game brings the commanders from the peacetime to wartime as if they were actually fighting and this provides them with a lot of experience to deal with the unstable events.

\subsection{Good Thinking and Discernment}

Winning a battle depends on the successful leadership that can take advantage of the available resources, take the opportunities and exploit the serious gaps and weaknesses of the enemy along with protecting the military forces from any losses or destruction. This cannot be achieved without much thinking and thus Al-Wakeel (1986, p. 149) claimed, in his book "Leadership and Soldiering in Islam" that "Islam promotes thinking and educating people especially the leaders for different reasons among which to raise the awareness of the leaders so as not to be deceived by the enemy, to enable them to thwart his enemy's plans and also to make plans to win the battle".

Moreover, Al-Humaidi (1999, p. 26) argued, in his article "military training" in the National Guard magazine, that war game has a major role in developing the critical thinking skill since it is considered as an exercise to the mind. It helps develop the intellectual abilities of the commanders. This war game puts the commanders in a situation similar to that in the reality as well as sudden events that they must urgently deal with properly. Such situations and events force the commander to look at them from different angles and do his best to sort out such issues. Such experience surely develops the commander's thinking appropriately".

\subsection{THE ROLE OF WAR GAME IN EDUCATING THE STAFF}

Every commander has his own advisers selected from the qualified officers. These are called the Authority of Staff. The preparation and rehabilitation of those Staff is of great significance because of the fact that they are assistants to the commander and help set some military plans besides the commander. They are concerned with making the orders as well as plans and the arrangements for

Page | 5 
decisions. Their work often depends on gathering information and preparing reports which are based on either on facts or assumptions. Therefore, they need to use war game so much. Al-Harthi (2001, p. 93) mentioned all these uses in his essay entitled "the role of thought in the mission of the authority of staff" which was published in the Faculty Mission Magazine. Al-Harthi pointed out that such uses include the following: the preparation of various reports, successful war plans design, creativity and innovation in setting the assumptions and possibilities which are close to reality and the ability to anticipate enemy's potential intentions when there is a lack of information during the battles.

War game also helps the staff in respect of the methods of analysis so as to select the way by which someone can carry out the tasks in a good way. The analysis can be conducted through doing each solution method separately, recording the advantages and disadvantages, their effectiveness in carrying out the task and, and making a comparison among all solution methods and finally choosing the appropriate way to perform the task.

\subsection{THE ROLE OF WAR GAME IN EVALUATING THE COMMANDERS AND STAFF}

War game helps provide knowledge about the potential of the commanders and staff. Moreover, it assists in discovering their talents through putting them in situations similar to what occurs in wars so as to find out how they react in such situations and how they deal with such events (Perla, 1990). Therefore, the war game provides an accurate measure of the ability of the commanders and staff to deal with the sudden events, to make decisions and conduct good analysis, all of which result in finding out more about their talents. This is useful when it comes to placing the commander in the right position where he can show his talents. Such creativity will not be only useful to the commander but also the military unit and its development. Therefore, the war game can be considered a successful means of evaluation for commanders and staff.

\subsection{CONCLUSION}

War game has become an essential means for rehabilitating the commanders due to its great benefits. This is because of the close relation between war game in this era and the computer systems which give high degrees of accuracy in the results whenever the inputs are correct. Moreover, what gives the war game the priority among other means is its flexibility in use and its scalability based on recent information. Most importantly, the strongest reason why the war game is more favorable is related to the rationalization of the military equipment which cost a lot.

\subsection{Concluding Remarks}

From this discussion, there are several conclusions can be drawn;

1. Great countries pay much more attention to war game. They depend on the results of such war tournaments which they make especially the United States of America which established large centers for the war game and also have allocated huge amounts of money to carry out such plays.

2. The developed countries have achieved advanced levels of military aspects because of their great interest in studying the future with all its repercussions, developing the necessary plans for future events, working to implement such plans and studying their feasibility in order to identify the aspects

Page $\mid 6$ 
of strength to develop them and also to recognize the aspects of weakness to resolve them. In fact, the war game is among the means which such countries rely on heavily.

3. The Islamic countries are the least countries which use war game. It seems that there is no reason to ignore the war game since it is very useful.

4. The most important reason why the war game has been developed is the nuclear war which was expected between the United States and the Soviet Union. Many translated references have reported many wars tournaments which are carried out in this regard.

5. In the past, the war tournaments take military and political nature but the vision has become different in today's world where the play has become relevant to the centers of decision-making at various levels and in all authorities.

6. The most dangerous use of war game lies in its use to make a decision of war.

7. The notion of war game is commonly associated with the preparation (scenario) of war only. In fact, this is not true in that the basic concept of war game is concerned with providing a similar picture of the battle with all its events in order to achieve several aims among which training, investigation, analysis and other purposes.

\subsection{Recommendations}

There is a pressing need to adopt a course of war game among the courses taught in the Command and Staff College due to the fact that the war game has a leading role in the training of commanders, especially in the domain of decision-making and provides the corner stone of planning and investigation, all of which benefit the college enormously.

It is of vital importance to establish specific centers for war game in the military colleges in order

to gain advantages of the potential of this means, especially in the training and rehabilitation of Command and Staff at all levels.

\section{References}

Abed, S. S. (1994). The Magazine of the National Saudi Guard. No. 131. Riyadh.

Al-Harthi, H. M. (2002). The Faculty Mission. No. 9. Riyadh.

Al-Humaimidi, M. A. (2000). The Magazine of the National Saudi Guard. No. 209. Riyadh.

Al-Omari, M. Z. (2002). The Magazine of King Abdulaziz's Military Faculty. No. 42. Riyadh.

Al-Otaibi, S. A. (1998). The Magazine of the National Saudi Guard. No. 191. Riyadh.

Al-Shahri, A. H. (1999). The Magazine of the National Saudi Guard. No. 201. Riyadh.

Al-Wakeel, M. (2006). Leadership and Soldiering in Islam. 2nd edition, Mansoura, Dar Al-Wafa.

Al-Zaini, A. (1997). The Magazine of Gulf Defense. No. 31. United Arab Emirates. 
Asiri, N. Y. (2002). The Faculty Mission. No. 9. Riyadh.

Corthoa, J. (1998). Profiles in the Art of Leadership. 2nd edition, Beirut: The Arab Foundation.

Egyptian Command and Staff College. (2000). The Guide of the Competitors in War Tournaments. Cairo. https://defence.pk/pdf/threads/egyptian-command-and-staff-college.435766/. Retrieved 2019-07-03.

Ibn Manzur. (1968). Lisan al-Arab. Beirut: Dar Sader.

Johnson. J. (2014). The Four Levels of Wargaming: A New Scope on the Hobby. (https://www.beastsofwar.com/historical/levels-wargames-exploring-scopes-hobby/). Retrieved 2019-0703). 